\title{
The effect of cartoon on children
}

\author{
PRIYAMBADA TRIPATHI, ANITA SINGH AND ANITA SINGH
}

Received: 05.07.2016; Revised: 26.10.2016; Accepted: 07.11.2016

See end of the paper for authors' affiliations

\section{ANITA SINGH}

Department of Food and Nutrition, Shri Agrasen Kanya P.G. College, VARANASI (U.P.) INDIA
ABSTRACT : Background : Child is like a white paper. Which you can draw on it, his personality and behaviour. A child is accepting any outer influence and information affecting his character in the future. Since any behaviour or action the child sees may affect his personality. Television is what attracts the children most and shapes their behaviour. Usually most of the shows that children's watch is cartoons. Cartoons are one of the daily habit for our children, but cartoon effects the child positively and negatively both. So to know that how a cartoon affects children, researchers choose this topic for research. Aim : The present study aimed to know positive and negative effects of cartoon on children. Methodology: A survey based descriptive research design was used to main aim of study. Location: This study was conducted at area of Surajkund and Madhopur in Gorakhpur city of U.P. Sample size : For these study 100 parents of children in the age group of 3-6 years was selected. Result: This study revealed that children are highly influenced by the cartoons and parents are not satisfied by positive effects of cartoons on their children.

KEY WORDS: Cartoon, Children

- HOW TO CITE THIS PAPER : Tripathi, Priyambada, Singh, Anita and Singh, Anita (2016). The effect of cartoon on children. Asian J. Home Sci., 11 (2) : 400-403, DOI: 10.15740/HAS/AJHS/11.2/400-403. 